\title{
An Evaluation of Differential Methylation of Ribonucleic Acid in Cystic Fibrosis
}

\author{
M. E. Hodes, ${ }^{[14]}$ A. Donald Merritt, and Jane T. Glier \\ Department of Medical Genetics, Indiana University Medical Center, Indianapolis, Indiana, USA
}

Extract

No differences were found in the methylation of total nucleic acids, total RNA, DNA, tRNA, or rRNA from lymphocytes or fibroblasts obtained from normal subjects, obligate heterozygotes, or individuals with cystic fibrosis. Similar results were obtained using four methods for isolation of the nucleic acids.

\section{Speculation}

The reasons for the failure of two laboratories to discern the reported variations in methylation of RNA in the normal, carrier, or cystic fibrosis state may be obscure differences in culture conditions or conditions of extraction. 


\section{Introduction}

Many unsuccessful attempts have been made to determine the underlying blochemical defect in cystic fibrosis (CF). Most recent1y, Rennert et al. $[6,7]$ reported that patients with the disease and their heterozygote paren methylate the tRNA of lymphocytes and skin fibroblasts to a lesser extent than do normal individuals. This is potentially a very important finding and
we attempted to confirm it using the methods out11ned by Rennert $[6,7$, and personal communications] and others. We were unable to find any difference in the extent of methylation of either RNA or DNA in lymphocytes or skin fubroblasts of nornal (C/C), heterozygote (C/c) or $\mathrm{CP}$ (c/c) lndividuals. examination of the skin fibroblasts of a smaller population.

\section{Materials and Methods}

Probands were taken from CF familles under study. A1l had elevated sweat chlorides and typical CF symptomatology. Skin biopsies and heparinized venous blood samples were obtalned from probands, their parents, a few siblings and ppesuaed norkal controls (C/ 0.95 probabilty of $\mathrm{C} / \mathrm{C}$ ). Leukocytes were separated from the blood by gravity sedimentation and the 1ymphocytes cultured in Gibco $1 \mathrm{~A}$ medium for two days. They were the (14 C-Met, $46.3 \mathrm{mCl} / \mathrm{mmole})$. Clumping of the cells made $1 \mathrm{t}$ difficult to relat ${ }_{14} \mathrm{C}$ uptake to cell number. Therefore $10 \mu \mathrm{HCl}$ of $5-{ }^{3} \mathrm{H}$-uridine $\left({ }^{3} \mathrm{H}-\mathrm{v}, 10.5\right.$ $\mathrm{C} 1 /$ manole) was added to label $\mathrm{RNA}$, and results are reported as the ratio of methylated $\left({ }^{14} \mathrm{C}\right)$ to total $\left({ }^{3} \mathrm{H}\right)$ RNA. After 24 hours in labeled medium, the cells were collected and tRNA (and DNA) was separated as described by Rennert $[6,7]$ (Method 1). Pibroblasts were obtained from skin with the
a1d of trypsin and were sown $\left(2 \times 10^{6}\right.$ cells) in $75 \mathrm{~cm}^{2}$ Falcon flasks in Eagle's
MEM [10] or $\mathrm{p}-10$, each supplemented w1th $15 \%$ fetal calf serum, 30 mM HEPES

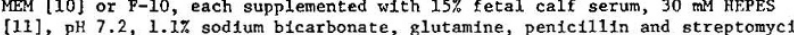
$(100 \mathrm{u} / \mathrm{ml})$. Cells were orown for several days unt 11 they were confluent and fresh medium containing $2 \mu \mathrm{CC}$ each of ${ }^{14} \mathrm{C}-\mathrm{Met}$ and $3 \mathrm{H}-U$ were added. In some exper ments the labels were reversed: $3 \mathrm{H}-\mathrm{Met}(1.2 \mathrm{Cl} / \mathrm{mmole})$ and $\mathrm{i4} \mathrm{C}-\mathrm{U}$
$(160 \mathrm{mC} 1 / \mathrm{mm}$ le) were used. Incubation was continued for $20-24 \mathrm{hr}$., the (160 mC1/mmole) were used. Incubation was continued for $20-24 \mathrm{hr}$., the monolayer washed
ac1ds extracted.

Nucleic acids were 1solated as described by Rennert $[6,7]$ for the experiments with lymphocytes (Method 1). In the fibroblast experiments, separation of the DNA and tRNA by the Drasher [1] modification of the method of Schmidt and Thannhauser [8] (Method 2). In a few experiments total nucleic acids were precipitated from crude cell extracts with cetyltrimethyl ammonium bromide [2] (Method 3). In 2 experiments the nucleic acids were \{ractionated on sucrose gradients containing sodium dodecyl sulfate [3] (Method 4). The detalls are described in the legend to F1g. 1. Nucleic acids were solubilized in NCS [12] solubilizer and counted in POPOP-PPO toluene in a Packard 1iquid scintillation counter. Data were corrected for the 1sotopes calculated by computer.

\section{Results}

The cultured lymphocytes from the members of 8 familles were examined by Method 1 (Table 1). In only 2 instances (Families 5 and 6) did the ratio of methylated to total RNA appear significantiy lower In the family members among the samples.

The f1broblasts from 6 families were examined with $14 \mathrm{C}$-methionine and

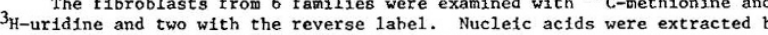
Method 2. It was not possible to distinguish among the genotypes in any instance. An example of the results is given in Table 2 .

In another experiment the methylation of the total nucleic acids (obtained by Method 3) of one obligate heterozygote, one CF patient, one sibling an

The RNA obtained from fibroblasts of a CF patient, an obligate heterozygote, and a normal heavily labeled with ${ }^{3} \mathrm{H}-\mathrm{Met}$ was separated on a sucrose density gradient (Method 4) in two experiments. The results obtained in one experiment are shown in Fig. 1. In neither case were there differences in the methylation of either TRNA or tRNA.

\section{Discussion}

The results presented here indicate that nucleic acids in general and tRNA in particular obtalned from 1ymphocytes or skin fibroblasts are as fully methylated in $\mathrm{CF}$ as they are in normal cells. These findings contrast with those of Rennert and coworkers $[6,7]$ but are similar to those of Klagsburn and
Farrell [5]. The latter used f1broblasts in their work and suggested that Farrell [5]. The latter used f1broblasts in their work and suggested that the diffexences from Rennert's results might owe to the different growth conditions used by each group. This possible explanation is not a likely one, for our experiments like Rennert's were performed on confluent cells, and blasts. (Mereover stillar wesults were obtained phecytes as well as fibroDNA, rRNA or tRNA (i.e., those species known to be methylated in mammalian cells) were examined. The reasons for the differences in the results obtalned in Rennert's and the other 2 laboratories remain obscure. However, despite careful contro1, it is a truism that conditions for the cultures of tissues differ among laboratories in subtle ways and some such factor could conveivably account for the differences noted. Differences in extractio procedure may result in divergent partition of the nucleic acids in the oxganic and aqueous phases, a variable that would probably not af fect $t$ extent of methylation cannot be recommended for distingutshing the vartous genet1c states of $C F$.

\section{References and Notes}

. Drasher, M. L.: Criticism of the Indiscriminate use of the Schmidtthe Thannhauser method for the fraction
material. Sc1ence, 118:181 (1953).

2. Dunn, A.: Use of cetyl trimethyl ammonum bromide for estiration of the

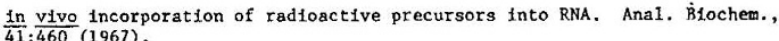

3. Ewton, D., and Hodes, M. F.: Nucletc acid synthesis in Hela cells in-

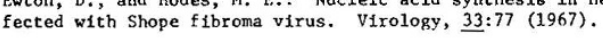

4. Klagsburn, M.: The contrast between the methylation of transfer ribo-

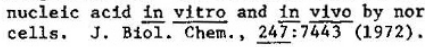

5. Klagsburn, M., and Farre11, P. M.: The methylation of RNA in fibroblasts of normal volunteers and patients with cystic fibrosis. In: J. A. Mangos and R. C. Talamo: Fundamenta1 Problems of Cystic Fibrosis and ReT̈ated Diseases, p. 44. (Intercontinental Medical Book Corporation,
New York, 1973).

6. Rennert, O. M., Frias, J. L., Julius, R. L., and LaPointe, D.: The deteclymphocyte culture studies: A defect in RNA methylation. Clin. Pediatrics, 11: 351 (1972).

7. Rennert, O. M., Julius, R. L., and LaPointe, D.: RNA methylation --a
possible genetic marker in cystic f1bros1s. Pediatrics, $50: 485$ (1972).

8. Schmidt, G., and Thannhauser, S. J.: A method for the determination of desoxyribonucleic acid, ribonucleic acid, and phosphoproteins in anima. tissues. J. B1o1. Chem., 161:83 (1945).

9. Sein, K. T., Bécarevíc, A., and Kanaz1r, D.: A simple modified method for the extraction of rat liver sRNA. Anal. Biochem., 28:65 (1969).

10. Minimum essential medium (Eag1e), Auto-Pow, Flow Laboratories, Rockville, Maryland.

11. N-2-hydroxyethylpiperazine-N -2 -ethanesulfonic ac1d, Calbiochem, La Jolla, California.

12. Amersham/Searle, Arlington Heights, Illinois.

13. Supported in part by PHS Research Grant AM12328-04, The Indiana E1ks, and the J. W. Riley Memorial Association.

14. Requests for reprints should be addressed to: M. F. Hodes, M.D., Department of Medical Genetics, Indiana University Medical Center, Indtanapolis, Indiana 46202 (USA).

15. Accepted for publication November 14,1973

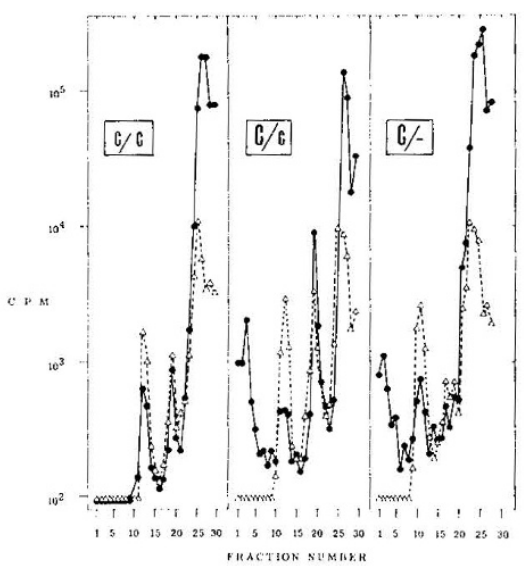

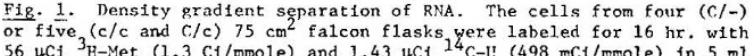
$56 \mu \mathrm{Cl} 3 \mathrm{H}$-Met $(1.3 \mathrm{Cl} / \mathrm{mmole})$ and $1.43 \mu \mathrm{Cl} 14 \mathrm{C}-\mathrm{tl}(498 \mathrm{mCl} / \mathrm{mmole})$ in $5 \mathrm{ml}$ of $F-10$ medium: $15 \%$ fetal calf serum containing $1 \times 10^{-4} \mathrm{M}$ adenosine [4]. The cells were washed, scraped from the bottles and 1ysed in hypotonic
buffer. The cytoplasm was separated af ter treatment in a teflon-1n-plass buffer. The cytoplasm was separated af ter treatment in a teflon-1n-pla homogentaer, $20^{\circ}$ in Sninco rotor SN25.i at $23,000 \mathrm{rpm}$. The tubes were fractionated from the bottom. (to the $1 \mathrm{eft}$ ), $1 \mathrm{ml}$ fractions collected, the $\mathrm{A}_{2} 60$ determined and trichloracetic actd insoluble material collected on GF/A filters. These were washed, dried, solubilized with NCS solublizer and counted in dimethyl popto $\mathrm{A}_{260}$ pattern corresponded to tho shown for radil 
Table 1. Methylation of tRNA of 1ymphocytes ${ }^{1}$

\begin{tabular}{|c|c|c|c|c|}
\hline \multirow[b]{2}{*}{ Fam $11 y$} & \multicolumn{4}{|c|}{${ }^{14} \mathrm{c} /{ }^{3} \mathrm{H} \times 10^{5}$} \\
\hline & $\begin{array}{l}\text { Affected } \\
\mathrm{c} / \mathrm{c}\end{array}$ & $\begin{array}{l}\text { Mother } \\
\text { C/c }\end{array}$ & $\begin{array}{l}\text { Pather } \\
\text { C/c }\end{array}$ & $\begin{array}{l}\text { Control } \\
\mathrm{c} /-\end{array}$ \\
\hline 1. & 684 & 365 & 401 & 746 \\
\hline 2. & 57 & 45 & 43 & \\
\hline 3. & $\overline{---}$ & & 126 & 91 \\
\hline $\begin{array}{l}4 . \\
5 .\end{array}$ & $\begin{array}{r}93 \\
375\end{array}$ & 255 & 93 & 102 \\
\hline $\begin{array}{l}5 . \\
6\end{array}$ & $\begin{array}{l}375 \\
985\end{array}$ & 573 & 381 & 1400 \\
\hline & 985 & 712 & 867 & 1596 \\
\hline & 115 & 360 & 733 & 561 \\
\hline 8. & 721 & 937 & 756 & -- \\
\hline
\end{tabular}

Table II. Methylation of tRNA and DNA of fibroblasts ${ }^{1}$

\begin{tabular}{|c|c|c|c|c|}
\hline Label & Diagnosis & Combined NA & tRNA & DNA \\
\hline${ }^{3} \mathrm{H}-\mathrm{Met} /{ }^{14} \mathrm{C}-\mathrm{U}$ & $\begin{array}{l}\text { Mother }(\mathrm{C} / \mathrm{c}) \\
\text { Father }(\mathrm{C} / \mathrm{c}) \\
\text { Nornal }(\mathrm{C} / \mathrm{)}) \\
\mathrm{CF} \quad(\mathrm{c} / \mathrm{c})\end{array}$ & $\begin{array}{l}.337 \\
.319 \\
.371 \\
.296\end{array}$ & $\begin{array}{l}.338 \\
.394 \\
.383 \\
.380\end{array}$ & $\begin{array}{l}.277 \\
.243 \\
.264 \\
.260\end{array}$ \\
\hline${ }^{14} \mathrm{C}-\mathrm{Met} /{ }^{3} \mathrm{H}-\mathrm{U}$ & 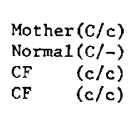 & $\begin{array}{l}.015 \\
.015 \\
.015 \\
.022\end{array}$ & $\begin{array}{l}.016 \\
.014 \\
.014 \\
.021\end{array}$ & $\begin{array}{r}.059 \\
.049 \\
.049 \\
--\end{array}$ \\
\hline
\end{tabular}

${ }^{1}$ The nucleic acids were extracted and separated by Method 2 . 
Glucose Phosphate Isomerase Deficiency with Congenital Nonspherocytic Hemolytic Anemia: A New Variant (Type Nordhorn) I. Clinical and Genetic Studies

By W. Shröter et al.

Pediatric Research, Vol. 8, No. 1

p. 18 and Contents-Dr. Arnold's name should have appeared as "H. Arnold" instead of "A. Arnold." 